\title{
B-10＼cjkstart歩行中にお恔る腰部加速度からのステップ長の推定
}

\section{The estimation of step length from trunk acceleration during walking}

\author{
○日暮 菜雄（東工大院）。正 丸山 剛生（東工大）
}

Nao HIGURASHI, Takeo MARUYAMA

Tokyo Institute of Technology, 2-12-1 Oh-Okayama, Meguro-ku, Tokyo

\begin{abstract}
The purpose of this study was to verify the validity of the inverted pendulum model in one step and to propose new models which could accommodate to the several walking speeds. Twelve subjects walked about $10 \mathrm{~m}$ path at three kinds of walking speeds. Lower trunk acceleration and 3D marker data were recorded. True value of the step length was recorded from $3 \mathrm{D}$ marker data and predicted value was calculated by inverted pendulum model whose variable was displacement of the COM. Displacement of the COM was calculated by double integration of the lower trunk acceleration. We proposed the new model which changed the correction factor $\left(\mathrm{K}_{\mathrm{m}}\right)$ in each step with using regression equation. We evaluated the validity of the model by RMS. From the result of this study, the validity of the new model was higher than previous models at all speeds in each step. So it was suggested that new method was better estimator of the step length than previous models.
\end{abstract}

Key Words: Step length, Acceleration, Accelerometer, Inverted pendulum model, Multiplied regression

\section{1. はじめに}

歩行は二脚で重心を前方へ移動させる動作である。また、 人は一日に平均 1 万歩弱歩いているといら先行研究[1]加ら、 歩行は人間の基本的な動作であり、かつ非常に重要な動作 であると言える。この歩行には、歩行距離、歩行速度、ピ ッチ、歩隔などの様々なパラメータがある。このパラメー 夕の中でも非常に重要であるのがステップ長である。ステ ップ長は歩行距離の基本単位であり、ステップが何度も繰 り返されることによって歩行が行われ、歩行距離を得るこ とができる。このようなことから、臨床現場での歩様の正 常さの判断や、レクリエーション現場での歩行距離の把握、 スポーツ現場でのパフォーマンス評価の指標として利用さ れている。

近年、ステップ長計測機器で注目されているのが加速度 計である。従来の計測機器は床反力計やモーションキャプ チャシステム、ヘトドメーターであったが、床反力計やモー ションキャプチャシステムは時間的・空間的に制限された 計測しか行えず、ペドメーターはステップ数などの簡易的 な指標しか計測できないという問題点がある。しかしなが ら、加速度計は軽量・小型であり身体に取り付计たまま動 作を行えることから、時間的・空間的に影響されない歩行 動作の計測に適している。また、動作を加速度という形で 記録できることから、歩行を評価する指標を多く得ること も可能である。

この様なことから、先行研究では加速度計を用いた歩行 中のステップ長推定が行われている。Aminan et al.[2]は腰 部と踵部に加速度計を装着し、その波形を二ューラルネッ トワークに入れることで、ステップ長を予測している。し かしながら、ニューラルネットワークを用いたAminianの 研究はステップ長算出の為の計算時間が長時間掛かったり、 加速度計を腰部と踵部に装着するこ上で煩雑であるという 久点があった。そこで提案されているのが、本研究で用い る逆振り子モデルである。これは Zijlstra et al.[3]が提案した もので、歩行時の1ステップ中の鉛直方向重心軌跡 $(\mathrm{COMz})$ 老逆振り子モデルに当てはめたモデルである。この逆振り 子モデルは単純な三角関数の計算からステップ長を予測で きることから計算時間もかからず、腰部に加速度計を一つ 装着するだけであるため動作に影響老与えにくい。
逆振り子モデルを用いた先行研究において、Zijlstra et al.[3]は腰部加速度から得られた 1 ステップ中の重心変化量 を逆振り子モデルに当てはめ、ステップ長を予測した。し かしながら、簡易的であった反面、予測式の精度がそしく ステップ長を過小評価する問題があった。そこで、Brandes et al.[4]は禣正係数と呼ばれる定数を被験者每にキャリブ レーション試行から決定し、Zijlstra et al.が提案した逆振り 子モデルに掛け合わせることで、より精度良くステップ長 を算出する提案を行った。予測精度はZijlstra et al.の先行研 究と比較して格段に向上したが、補正係数を決定するため のキャリブレーション試行を一つの速度のみで行っていた ことから、予測試行において歩行速度が速い場合や遅い場 合には子測精度が低下するという問題点があった。

更なる予測精度の向上を目的として Alvarez et al.[5] や Gonzalez et al.[6]は 1 ステップを片脚支持期(SS： Single Stance 期) と両脚支持期(DS 期：Doubule Stance 期)に分け、 SS 期に逆振り子モデルを、DS 期に足部長を用いてステッ プ長を予測するモデルを提案した。しかしながら、予測精 度は高かったが、腰部加速度から SS 期と DS 期を分割する ための接地(HS：Heel Strike)と離地(TO：Toe Off)を判定す る必要があり、加速度からでは必ずしも TO を判定できな い試行があるという問題があった。よって、SS 期・DS 期 の区别老必要上せずに S2 上同等、もしくはそれ以上の予 測精度を持った算出式が必要である。

また、上記の逆振り子モデルを用いてステップ長を予測 する先行研究では、一定の歩行距離を予測し、その值をス テップ数で除することで平均のステップ長を予測すること が行われている。しかしながら、この手法では各ステップ における予測精度は議論されておらず、算出されたステッ プ長が真值を表しているとは限らない。1 ステップを精度 よく予測できるかどらかが重要であるのにも関わらず、そ の上らな先行研究は行われていない。

よって、本研究では、先行研究の問題点を解決するため に、Zijlstra et al.[3]が提案した SS 期・DS 期の区分けを必要 としない逆振り子モデルの補正係数Kの決定方法を改良し た新しいモデルを提案し、異なる歩行速度におけるステッ プ毎のモデルの妥当性を検証すること老目的とした。 


\section{1. 被食者}

\section{2. 実政方法}

本研究には健常な成人男性(11 名) ・成人女性(1 名)门計 12 名（年齢 $24.9 \pm 1.6$ 歳、身長 $170.7 \pm 7.4 \mathrm{~cm}$ 、体重 63.3 $\pm 12.2 \mathrm{~kg}$ 、足部長 $25.6 \pm 1.6 \mathrm{~cm}$ 、重心高 $97.4 \pm 5.0 \mathrm{~cm})$ が参 加し、実験前にインフォームドコンセントを得た。被験者 には動きやすい格好をしてもらい、素足で実験を行った。 重心高は加速度計を貼り付ける高さである上後腸骨棘 (PSIS)の中点の高さとした。

\section{2. 武行}

被験者には、約 $10 \mathrm{~m}$ の直線路を 3 種類の歩行速度で歩行 してもらい、定常歩行部分のデータのみを解析対象として 記録した。歩行速度は Normal、Slow、Fastである。Normal は被験者の最も歩きやすい歩行速度である。Slow は Normal よりも遅い速度、Fastは Normalよりも速い速度とした。速 度は規定せずに被験者の主観的な速度とした。歩行速度は Normal : $1.38 \pm 0.17 \mathrm{~m} / \mathrm{s}$ 、Slow : $0.99 \pm 0.14 \mathrm{~m} / \mathrm{s}$ 、Fast : $1.70 \pm$ $0.17 \mathrm{~m} / \mathrm{s}$ であった。得られた試技の中から各歩行速度で 4 試行、計 12 試行を補正係数 $\mathrm{K}$ を決定するためのキャリブ レーション試行に用いた。残りの試行を予測試行とし、そ こで得られたステッブ長の真值と予測值を用いてモデルの 妥当性の検証を行った。

\section{3. 渭定項目}

測定項目は、3 次元画像データ、腰部加速度とした。

\subsubsection{3 次元画像データ}

身体ランドマークに貼り付けたマーカを 3 次元動作解析 システム(Motion Analysis 社製)を用いて撮影した。カメラ スピードは200fps とした。ランドマークに貼り付けたマー 力は、左右踵骨隆起、左右第二中足骨骨頭の計 4 点とした。

\subsection{2. 加速度計}

3 軸加速度計(S\&ME 社製、圧電式、 $\pm 10 \mathrm{G})$ により腰部 3 軸加速度を記録した。サンプリング周波数は $200 \mathrm{~Hz}$ とした。 装着場所は左右 PSIS $の$ 中点とした。PSIS $の$ 中点に貼り付 けた理由として、モデルに必要な身体重心部分の加速度を PSIS 中点の加速度で代用でき、から、身体ランドマークが あり加速度計を貼り付けやすい部分であることが挙げられ る。確実に固定するために、木板に加速度計を固定した上 で、PSIS の中点に貼り付けた(Fig.1)。なお、今後、PSIS 中 点の加速度を重心加速度と定義する。得られた加速度は、 背中に装着したデータロガー(S\&ME 社製)に記録した。

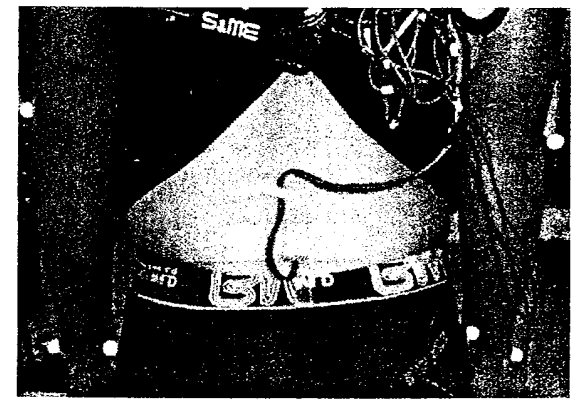

Fig.1: Accelerometer which is attached on the middle point of PSIS.

\section{1. 解析}

\section{3. 解析方法}

解析は Matlab7.0.1(The MathWorks 社製)によって行った。 ノイズ除去のために 3 次元画像データは $7 \mathrm{~Hz} 、$ 鉛直方向重 心加速度は $20 \mathrm{~Hz}$ 、前後方向重心加速度は $3 \mathrm{~Hz}$ のカットオ フ周波数で 2 次のローパスバタワースフィル夕を時系列的 に双方向から 2 度かけ平滑化した後、デー夕を同期した。

\section{2. 逆振り子モデル}

本研究では、歩行中の鉛直方向重心加速度 $(\mathrm{Az})$ を 2 階積 分することで算出した鉛直方向重心軌跡(COMz)から 1 氻 テップ中の鉛直方向重心変化量を求め、そ礼を逆振り子モ デルに当てはめることによって、ステップ長を予測する。 算出式は先行研究の算出式である S1、S2 と、本研究で提 案する算出式 Sh、Sp、Smの計 5つである。

\subsection{1. 予測式 $\mathrm{S} 1 、$ 及び $\mathrm{Sh} 、 \mathrm{Sp} 、 \mathrm{Sm}$}

式 $\mathrm{S} 1 、$ 及び $\mathrm{Sh} 、 \mathrm{Sp} 、 \mathrm{Sm}$ は、1 ステップ中の鉛直方向重 心変化量 $\left(h_{1}\right)$ と重心高 $(L)$ を逆振り子モデルに当てはめた算 出式である。このモデルは Zijlstra et al.[3]偍案した算出式 である(Fig.2)。3.3 で説明する決定方法で決定した補正係 数 $\mathrm{K}_{\mathrm{l}} 、 \mathrm{~K}_{\mathrm{h}} 、 \mathrm{~K}_{\mathrm{p}} 、 \mathrm{~K}_{\mathrm{m}}$ を式(1)の $\mathrm{K}$ に代入することによって得 られた算出式をそれぞれ Sl、Sh、Sp、Smとした。

$$
S=K * 2 \sqrt{2 L h_{1}-h_{1}^{2}}
$$

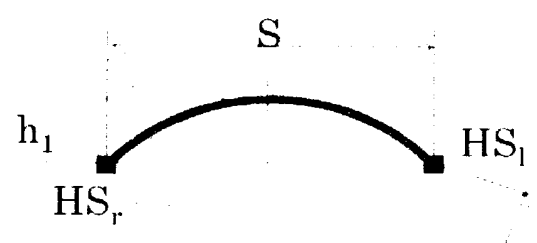

I.

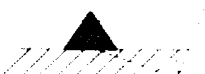

Fig.2: Inverted pendulum model which uses length $\mathrm{L}$ and displacement of $\mathrm{COM}\left(\mathrm{h}_{1}\right)$ in one step.

\subsection{2. 予测式 $s 2$}

式 S2 は Gonzalez R et al.[6]が提案したステッブ長算出式 であり、先行研究では最も精度良く歩行距離を算出する。1 ステップを加速度波形から SS 期上 DS 期に分け、SS 期で の距離老逆振り子モデル、DS 期での距離を足部長 F を用 いて予測するモデルである(Fig.3)。 $\mathrm{K}_{2}$ は補正係数であり、 3.3 で説明する決定方法で求めた。

$$
S 2=2 \sqrt{2 L h_{2}-h_{2}^{2}}+K_{2} * F
$$




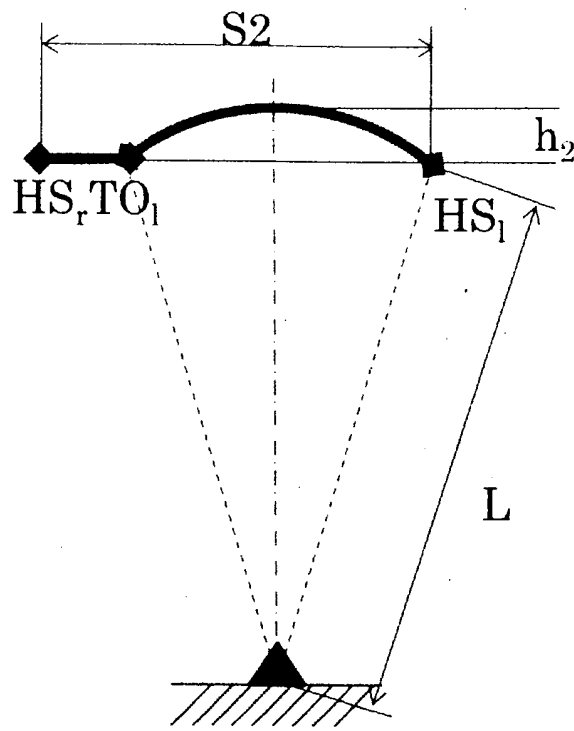

Fig3: Inverted pendulum model which uses length $\mathrm{L}$ and displacement of $\operatorname{COM}\left(h_{2}\right)$ in Single Stance phase.

\section{3. 㭪正係数 $\mathrm{K}$ の決定}

補正係数 $\mathrm{K}$ とは、予測試行を精度よく予測するための係 数である。5つの式における K はキャリブレーション試行 によって決定される。ここで得られた $\mathrm{K}$ を用いて予測試行 でステップ長の予測を行う。S1 と S2においては、先行研 究[4][6]乞同様の算出方法で算出した。

\subsection{1. 㭪正你数 $\mathrm{K}_{1}, \mathrm{~K}_{2}$ の決定}

12 試行のキャリブレーション試行から、歩行速度 Normal のみの 4 試行を補正係数 K 在決定する試行として用いた。 キャリブレーション試行では、ステップ毎に 3 次元画像デ 一タから得られたステップ長の真值と加速度から予測され たステップ長の予測值との比が算出される。この比をキャ リブレーション試行での全てのステップで算出し、平均化 することで $\mathrm{S} 1$ と 2 の補正係数 $\mathrm{K}_{1} 、 \mathrm{~K}_{2}$ を一つに決定する。

\subsection{2. 補正保数 $K_{h}, K_{p}, K_{m}$ の決定}

$\mathrm{Sh} 、 \mathrm{Sp} 、 \mathrm{Sm}$ は、先行研究の問題点である歩行速度変化 への対応を行うためのモデルである。12 試行のキャリブレ ーション試行を用いて、まず式 $\mathrm{S} 1$ から補正係数 $\mathrm{K}_{1}$ と $\mathrm{h}_{1}$ 、 ピッチを算出し、ステップ毎の $\mathrm{K}_{1} 、 \mathrm{~h}_{1}$ 、ピッチの組み合わ せを作る。この組み合わせを用いて、被説明変数を $\mathrm{K}_{1}$ とし

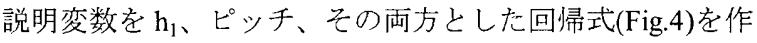
製し、回㷌式の係数 $\beta$ (式(3a) (3c)) を算出する。得られた $\beta$ と予测試行で加速度計から算出された $\mathrm{h}_{1}$ 、ピッチを用いて 式(3a) (3c)からステッブ毎に $\mathrm{K}_{\mathrm{h}} 、 \mathrm{~K}_{\mathrm{p}} 、 \mathrm{~K}_{\mathrm{m}}$ を算出し、予測

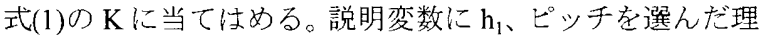
由として、歩行速度に影響を与える要因であること、加速 度計から計測可能な指標であることが挙げられる。

$$
\begin{aligned}
& K_{h}=\beta_{h 1} * h_{1}+\beta_{h 2} \\
& K_{p}=\beta_{p 1} * p+\beta_{p 2} \\
& K_{m}=\beta_{m 1} * h_{1}+\beta_{m 2} * p+\beta_{m 3}
\end{aligned}
$$

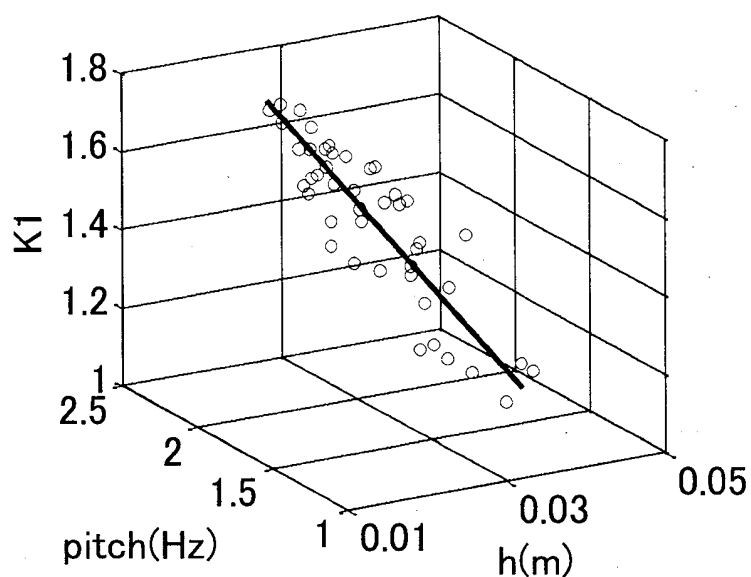

Fig.4: Scatter plot of $h_{1}$, pitch as explaining variable and $K_{1}$ as explained variable.

\subsection{3 次元画俊データからの HS・TOの規定}

本研究では、ステップ長の真值の算出と加速度波形切り 出しのために、接地(HS) ・ 離地(TO)の判定を 3 次元画像デ 一タから行った。HS・TOの判定は S2 では前後方向・鉛直 方向加速度の極值によって判定されているが、問題点とし て TO 在判定できない試行があることが挙げられる。よっ て、本研究では HS・TO を加速度からではなく、3 次元画 像データから求めた。HS・TOの判定は、O'Connor et al. [7] が提案した FVA (Foot Velocity Algorithm) を用いた。踵骨隆 起と第二中足骨骨頭の中点の鉛直方向成分の座標を算出し、 そのデータを微分することにより足部中点の速度(Vertical velocity of Foot：VVF)を算出した(Fig.5)。この波形から HS・TO 判定した。

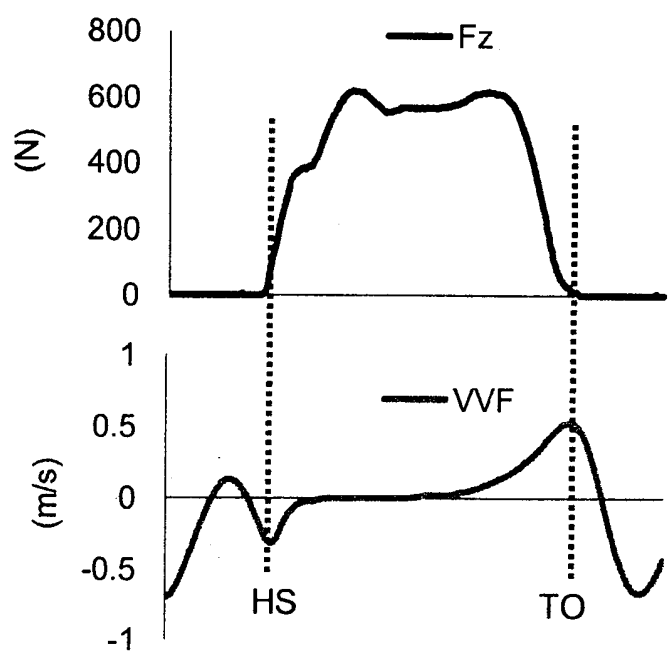

Fig.5:The FVA which predicts HS and TO from foot velocity. Figure above is the vertical ground reaction force. Figure below is the VVF. 


\section{5. 加速度からの重心变化量 $\mathrm{h}$ の算出}

予測式に必要な重心変化量 $h_{1} 、 h_{2}$ の值は、Gonzalez et al.[6]の先行研究を参考にし、Az 考 2 階積分することによ って得た。加速度データのドリフトを除去するために、歩 行路怔直線で平坦であるという事実から、1 ステップ中の 重心鉛直方向加速度と重心鉛直方向速度の平均值は 0 であ ると仮定し、以下の式(4a) (4d) 䒚用いてドリフトを補正し た(Fig.6)。その後、得られた COMz から $h_{1} 、 h_{2}$ を算出した (式(4e)、(4f))。

1) 1 ステップの加速度全体から、1 ステップにおける $\mathrm{A}_{z}$ の積分平均を減し、 $\mathrm{A}_{\mathrm{zc}}$ 算出する(式(4a))。

2) 1)で得られた $A_{z c}$ を 1 ステップの区間で積分し、加速 度計から得られる初速度 $\mathrm{V}_{\mathrm{z}}(0)$ を加えることで、 $\mathrm{V}_{\mathrm{z}}$ 在 算出守る(式(4b))。

3) 1)〜2)を再び繰り返し、COMz を得る(式(4c)、(4d))。

4) 1 ステップにおける $\mathrm{COMz}$ の最大值から最小值を減じ た值を $\mathrm{h}_{1} 、 \mathrm{SS}$ 期における $\mathrm{COMz}$ の最大值から最小值 を減じた值を $\mathrm{h}_{2}$ とする(式(4e)、(4f))。

$$
\begin{aligned}
& A_{z c}(t)=A_{z}(t)-\frac{\int_{H S_{l}(t)}^{H S_{r}(t)} A_{z}(\tau) d \tau}{H S_{l}(t)-H S_{r}(t)} \\
& V_{z}(t)=\int_{H S_{l}(t)}^{H S_{r}(t)} A_{z c}(\tau) d \tau+V_{z}(0) \\
& V_{z c}(t)=V_{z}(t)-\frac{\int_{H S_{l}(t)}^{H S_{r}(t)} V_{z}(\tau) d \tau}{H S_{l}(t)-H S_{r}(t)}
\end{aligned}
$$

$$
\operatorname{COMz}(t)=\int_{H S_{l}(t)}^{H S_{r}(t)} V_{z c}(\tau) d \tau+\operatorname{COMz}(0)
$$

$h_{1}=\max _{t \in\left[H S_{r}(t), H S_{l}(t)\right]}(C O M z(t))-\min _{t \in\left[H S_{r}(t), H S_{l}(t)\right]}(\operatorname{COMz}(t))$

$$
h_{2}=\max _{t \in[\text { SS phase }]}(\operatorname{COMz}(t))-\underset{t \in[\text { SS phase }]}{\min }(\operatorname{COMz}(t))
$$

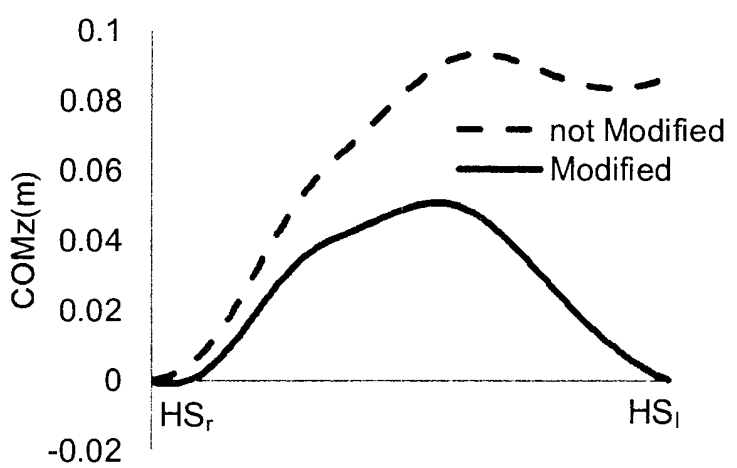

Fig.6 : Modified COMz and not modified COMz in one step.

\section{6. 加速度からのピッチ の算出}

ピッチの算出は、Zijlstra et al.[3]の先行研究老参考に前後 方向重心加速度 $(\mathrm{Ax})$ 加算出した。Ax 在カットオフ周波数 $3 \mathrm{~Hz}$ でフィルタリングして得られた加速度の極小值間の時 間の逆数をピッチとした。歩行時の身体重心は足部の接地
により減速されるために、接地によって Ax の極小值が計 測される。この極小值は周期的であるため、連続した極小 值を計測することでピッチを算出できる。

\section{7. 統計処理}

ステップ長の真值と各算出式による予測值の差を、ステ ッブ長の真值と予測值との請差を求め、真值で標準化した 式(5)の指標(nRMS : normalized Root Mean Square)によって 評価した。全速度を合わせて評価する場合は全速度での平 均で除し、速度毎に比較する場合は各速度の平均值で除し た。

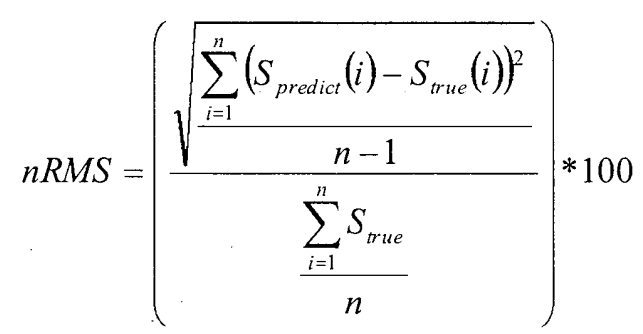

\section{4. 結果}

\section{1. 全速度における予湘㭗度}

予測試行における Normal、Slow、Fast 合わせた全試 行にお汁る予測精度の結果を Fig.7 に示す。

この結果から、逆振り子モデルの文用いた S1 と逆振 り子モデルと足部長を用いた S2 とを比較した場合、予測精 度はS2 の方が高い。ここ礼は先行研究と同じ結果が 1 ステ ップにおううる精度にも言えることを示している。 $\mathrm{S} 1$ と $\mathrm{Sm}$ を比較した場合、全速度を用いて補正係数を決定した $\mathrm{Sm}$ の方が、速度 Normal のみで禣正係数を決定したS1よりも、 予測精度が高いといら結果が得られた。交た、先行研究で 最も予測精度が高いS2 と新しい予測モデルである Smを比 較すると、S2よりも Smの予測精度が高いことが分かった。

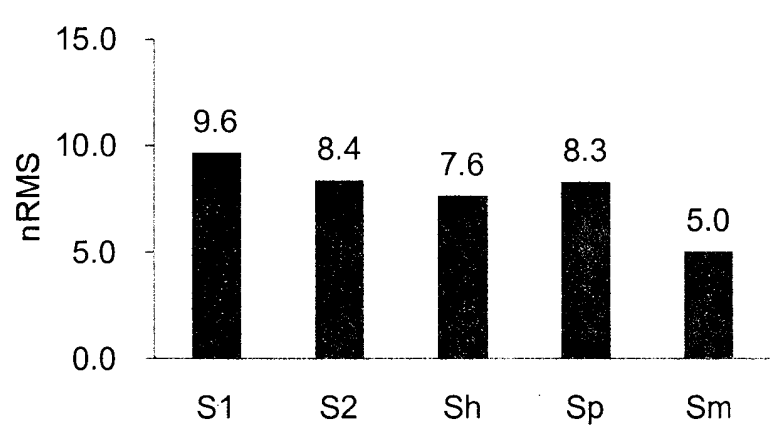

Fig. $7:$ nRMS at all speeds

\section{2. 各速度の予测精度}

予測試行における各速度での予測精度の結果を Fig.8 10 に記す。

S1 とS2 を比較した場合、どの速度においても S1よりも S2 で予測精度が高く、特に Fastで高いことが認められた。 
また、補正倸数以外で同じ式を用いる S1 と $\mathrm{Sm}$ 比較する 上、Smでは Slow、FastにおいてもnRMS がそれぞれ 5.8 と 5.4 であり、S1よりもnRMSの明らかな隇少が見られた。 先行研究で最も予測精度が高いS2 と新しいモデルである $\mathrm{Sm}$ を比較しても、S2 よりも $\mathrm{Sm}$ が全ての速度で予測精度 が高いという結果が得られた。

また、度每に比較した場合、3 種類の速度における 5 つ の算出式の $\mathrm{nRMS}$ の平均値は、予測精度が高い順に並べる と Normal : 4.8 であり、Fast: 7.9、Slow: 10.0であった。

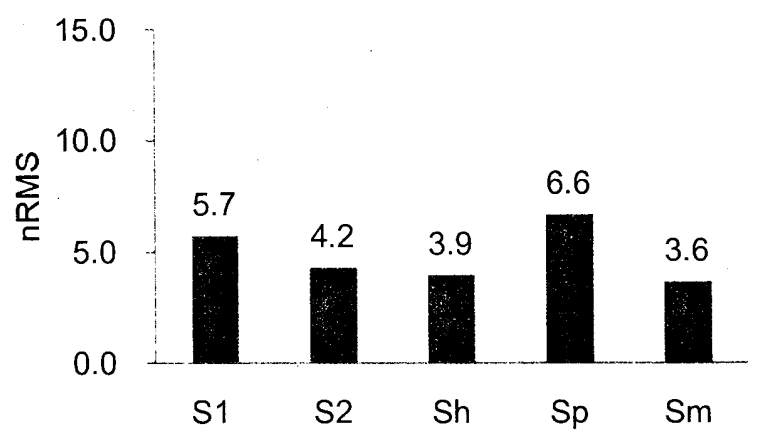

Fig. 8 : nRMS at Normal speed

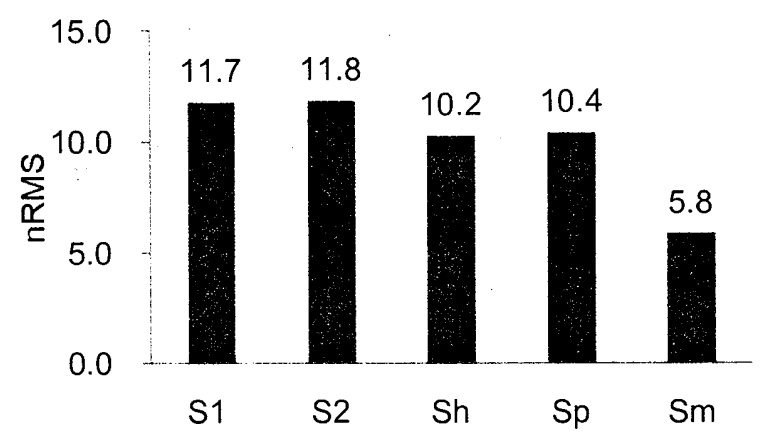

Fig.9 : nRMS at Slow speed

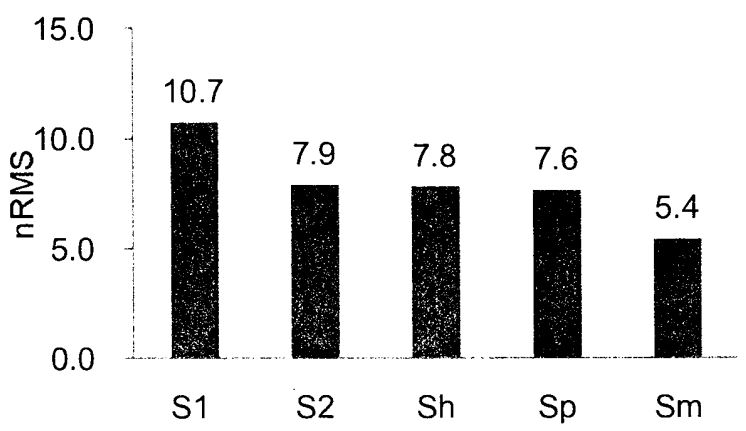

Fig. 10 : nRMS at Fast speed

\section{5. 考察}

\subsection{1 ステップにおけるモデルの妥当性}

先行研究において、逆振り子モデルを用いたステップ長 の推定は行われているが、予測した歩行距離をステップ数 で除することでステッブ長を孝測することしか行われてい
ない。よって、ステップ每では必ずしも正確な子測が行え ている上は限らない。本研究は、モーションキャプチャシ ステムを用いて 1 ステップにおうるるステップ長の真值を計 測し、加速度計加ら得られた予測值と比較した。結果、先 行研究で最も予測精度が高いS2 でも、全試行における nRMS が 8.4(Fig.7)であることが分かった。この值は先行研 究の值と比較して大きく、先行研究の手法が必ずしもステ ップ長の真值を算出していないことが示唆される。また、 先行研究のモデルである $\mathrm{S} 2$ 上、新しいモデルの中で $\mathrm{nRMS}$ が最小であった $\mathrm{Sm}$ を比較した場合、 $\mathrm{Sm}$ は $\mathrm{nRMS}$ が 5.0 上 S2 よりも低い值を示した(Fig.7)。よって、1 ステップにお いて、新しいモデルは従来のモデルよりも予測精度が高い ことが示唆される。

全体の傾向としては、歩行速度 Normal が最も予測精度 が高く、Fast、Slow の順に予測精度が低下することが分か った。理由として、歩行速度が異なることで歩行のストラ テジーが変化し、COMzが逆振り子モデルに当てはまりに くくなっていると予測される。Fig.8 と Fig.11 の結果から、 逆振り子モデルに最も当てはまりが良い歩行速度を Normal と仮定すると、歩行速度が増加・減少するにつれて $\mathrm{COMz}$ が逆振り子モデルに当てはまりづらい波形になって いることが見て取れる。特に Slow ではNormal と比較して $\mathrm{COMz}$ が極端に変形していることが分かる(Fig.11)。

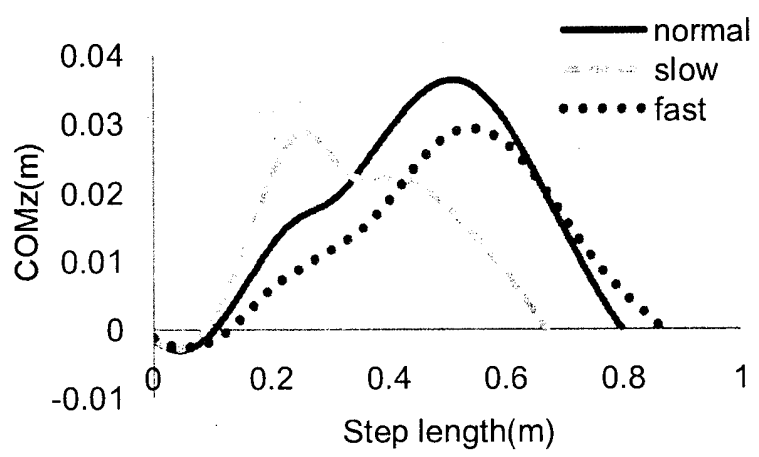

Fig. 11 : COMz at three kinds of walking speeds. $\mathrm{X}$ axis is the step length. $\mathrm{Y}$ axis is the displacement of COMz.

\section{2. 珫計モデルによる速度变化への対応}

先行研究の問題点として、歩行速度が異なる場合に対応 したモデルになっていない点が挙げられる。これは、補正 倸数決定の際に歩行速度 Normal のみで予測を行っている こと、また補正係数が一定值になっていることが原因とし て挙げられる。よって本研究では、統計的な手法孝用いて、 補正係数 $\mathrm{K}$ を決定する際に 3 種類の歩行速度での試技を用 い、ステップ毎に補正係数変換するモデルを提案した。 結果として歩行速度 Normal では、先行研究で予測精度が 高い S2 と新しいモデルを比較した場合、S2 : 4.2、Sh: 3.9、 $\mathrm{Sp}: 6.6 、 \mathrm{Sm}: 3.6$ であり、新しいモデル Shと Sm の予測精 度は S2 上变わらない。しふしながら、歩行速度がSlow と Fast の場合、S2 $の$ Slow : 11.8、Fast : 7.9 と比較して、Sm では Slow : 5.8、Fast : 5.4 と小さい。よって、Sm位先行研 究で提案されたモデルと比較して、上り歩行速度変化に対 応したモデルになっていると言える。Sh もSlow：10.2、 Fast：7.8であり、S2 と同等の予測精度があることが分かる。 また、Sm が最も予測精度が高いことから、補正係数 $\mathrm{K}$ 
を決定する際に用いる回㷌式の説明変数を $\mathrm{h}_{1}$ とピッチの どちらか一つにするのではなく、両方を説明変数とするこ とによって、ステッップ長の予測精度が向上することが示唆 される。こ礼は、被験者によって速度の增加・減少の要因 はステップ長を変化させることとピッチを変化させること の 2 要因があり、ビちらかまたは両方の要因が影響してい るからであると考えられる。よって、ステップ長を規定す る $\mathrm{h}_{1}$ とピッチの両方を含んだ $\mathrm{Sm}$ の予測精度が最も高い結 果を得られたと考えられる。

\section{6. まとめ}

本研究は、逆振り子モデルを用いたステップ長算出式の 補正係数 $\mathrm{K}$ をステップ每に変化させることによって、ステ ップ長の予測精度の向上させることを目的として行った。 新しいモデルと先行研究のモデルとを比較した結果から以 下のことが示唆された。

1) 新しいモデルの中でも補正係数 Kを決定する際に重心 変化量とピッチを説明変数よする回帰式を用いたモデ ル $(\mathrm{Sm})$ は、先行研究よ比較して1ステップにおける予 測精度が高い。

2) Sm は、先行研究と比較して歩行速度 Normal 以外の速 度でもステップ長の予測精度が高いことから、より歩 行速度変化に対応したモデルである。

\section{7. 考文献}

[1] Sequeira M. M. et al., Physical activity assessment using a pedometer and its comparison with a questionnaire in a large population survey. Am. J. Epidemiol., Vol.142, No.9, 1995, pp989-999

[2] Aminian K. et al., Incline, speed and distance assessment during unconstrained walking. Med. Sci. Sports Exerc. Vol.27, 1993, pp226-234

[3] Zijlstra W., Hof A. L., Assessment of spatio-temporal gait parameters from trunk accelerations during human walking. Gait and Posture, Vol.18, 2003, pp1-10

[4] Brandes M. et al., Accelerometry based assessment of gait parameters in children. Gait and Posture, Vol.24, 2006, pp482-486

[5] Alvarez D. et al., Comparison of Step Length Estimators from Weareable Accelerometer Devices. Proceeding of the $28^{\text {th }}$ annual international conference of the IEEE EMBS, Aug 30- Sep 26, 2006, pp5964-5967

[6] Gonzalez R. C. et al., Modified Pendulum Model for Mean Step Length Estimation. Proceeding of the $29^{\text {th }}$ annual international conference of the IEEE EMBS, August 23-26, 2007, pp1371-1374

[7] O'Connor C. M. et al., Automatic detection of gait events using kinematic data. Gait and Posture, Vol.25, 2007, pp469-474 